\title{
Assessment of Severity and Prognosis of Polytrauma Outcome: the Current State of the Problem (Review)
}

DOI: $10.17691 / \mathrm{stm} 2017.9 .2 .25$

Received November 10, 2015

P.A. Seliverstov, MD, PhD, Tutor, Department of General Surgery;

Y.G. Shapkin, MD, DSc, Professor, Head of the Department of General Surgery

Saratov State Medical University named after V.I. Razumovsky, 112 Bolshaya Kazachya St., Saratov, 410012, Russian Federation

The review deals with modern methods of assessing the severity and predicting the outcome of polytrauma.

To solve the problem of objective evaluation of polytrauma severity, numerous studies are devoted to the search for independent predictors of its outcome, many of which are included in various scales and statistical models to quantitatively rank the severity of injury in the established intervals and calculate the survival probability. It is generally accepted to take into account the anatomical criteria to determine the severity of damage, and physiological parameters that characterize the response of the body functional systems to the damage. Age, sex, comorbidities, various clinical parameters, indices of acidosis, coagulopathy, oxidative stress, inflammatory response, timely diagnosing and the quality of treatment, the need of rendering various types of emergency aid are considered as independent risk factors of fatal polytrauma outcome.

The predictive value and comparative effectiveness used in polytrauma scales assessing the severity of injuries (ISS, NISS, APS, ICISS, TMPM) and functional disorders (GCS, RTS, APACHE II, MODS II, SOFA, SAPS II, MPM II) as well as a variety of combined clinical and anatomical evaluation systems (TRISS, ASCOT, RISC II, PTS, etc.) are being actively discussed in the modern literature. Creating a universal scale is complicated by a variety of damages and disorders caused by a polytrauma, and insufficient study of injury outcome predictors. The proposed survival rates and prognostic factors are tied to specific polytrauma databases differing in terms of mortality and quality of medical care, which is reflected in their predictive value.

A clear definition of polytrauma and formation of a unified system of assessing its severity would allow physicians to standardize treatment policy, objectively solve the problems of organization and financial support of medical help to seriously injured people.

Key words: polytrauma; prognostic factors in polytrauma; mortality in polytrauma; scales and systems of injury severity evaluation.

In trauma distribution of recent decades, the proportion of severe multiple and combined trauma has increased substantially, with the injured population basically involving people of employable age. Treatment of such trauma requires enormous financial expenditure and mortality from it amounts to $30-80 \%$ [1, 2]. The variety of combination of body injuries and disorders occurring in polytrauma, the necessity to make quick decisions on diagnosis and treatment dictate the need for trauma severity classification. However, there is still no unified system of trauma severity evaluation, no clear widely-accepted objective criteria for reliable prognosis of trauma outcome, which complicates the selection of treatment policy, solving the problems of clinical and expert evaluation, medical care organization and financing $[3,4]$.

\section{Criteria for polytrauma and its severity}

The term "polytrauma" is widely used in European countries, the terms "multiple trauma" or "severe injury" are more often applied instead of it in the USA. Today, the term "polytrauma" describes severe multiple and combined injuries $[5,6]$. However, there is no agreement of opinions concerning trauma severity assessment criteria able to classify the injuries as polytrauma. When stratifying polytrauma patients, many authors rely on damage severity ranked on a scale of 16 and more with $17-25 \%$ risk of fatal outcome according to ISS (Injury Severity Score) [7, 8]. Others [9] consider the presence of several injuries assigned 2 scores in no less than two anatomical regions according to AIS (Abbreviated Injury Scale) to be relevant for diagnosing polytrauma. The international expert group suggested enhancing these anatomical criteria by the presence of at least one of the following physiological indices: 1) hypotension $\leqslant 90 \mathrm{~mm} \mathrm{Hg} ; 2$ ) level of consciousness $\leqslant 8$ scores according to GSC (Glasgov Coma Scale); 3) acidosis with base deficit $\leqslant-6.0 ; 4)$ coagulopathy with partial thromboplastin time $\geqslant 40$ or international normalization ratio $(I N R) \geqslant 1.4 ; 5)$ age over 70 years. Such polytrauma definition covers nearly $60 \%$ of all severe multiple trauma cases. When adding any of the five pathophysiological parameters, the predicted mortality level increases up to

For contacts: Pavel A. Seliverstov, e-mail: seliwerstov.pl@yandex.ru 
$35-38 \%$ and equals $86 \%$ among the patients presenting with all five factors $[2,10]$.

To solve the problem of objective trauma severity evaluation, numerous studies have been devoted to the search for independent predictors of fatal outcome, many of which are included in various scales and statistical models to quantitatively rank trauma severity in the established intervals and calculate survival probability. There are more than 50 various scales, but only those most effective and easy-to-use have been discussed in the literature [11].

Comparative assessment of scoring systems as to their effectiveness and predictive precision is carried out according to several statistical criteria. The method of logistic regression is used to determine the outcome probability and correlation between the outcome and its predictors. Quantitative analysis of scale calibration capability is based on comparing the distributions of expected and observed mortality and carried out according to the Hosmer-Lemeshow test. Discrimination ability of prognostic scales based on their sensitivity and specificity is determined by ROC-analysis (receiver operating characteristic curve) with calculating AUC (area under curve) which illustrates predictive value of the scale [12]. When using prognostic systems with a large number of variables, the problem of data insufficiency often occurs. In such cases, statistical MI (multiple imputation) methods allow scoring to be carried out without significant loss of predictive precision [13].

When evaluating polytrauma severity, it is generally accepted to take into account the anatomical criteria to determine the severity of damage, and physiological parameters that characterize the response of the body functional systems to the damage. Morphological component of polytrauma is relatively stable, while physiological indices are labile and capable of change in the course of treatment and in different periods of traumatic disease.

\section{Injury severity evaluation}

The most commonly used scoring system for evaluating trauma severity is AIS scale and ISS scale for which AIS is the basis. AIS scale ranks injuries from 1 to 6 scores, with score 1 being minor injury, score 2 - moderate, score 3 - serious non-life-threatening injury, score 4 - severe life-threatening injury, score 5 - critical injury with survival uncertain and score 6 - non-survivable injury. However, polytrauma severity evaluation with assigning the maximum score or summing AIS scores is not consistent with trauma outcomes and is not suitable for prognosis.

In ISS scale, trauma severity is calculated as the sum of squares of AIS codes awarded to three most severely injured body regions, i.e. the linear correlation of trauma severity with the injuries present is replaced by the square one [14]. By doing this, prevalence of the most severe injuries is determined. Evaluation according to ISS scale is in positive correlation with mortality and reflects the severity of injuries in polytrauma more objectively $[1,15,16]$. However, similar severity score for different injuries far from always corresponds to their predictive value for polytrauma outcome. AIS and ISS scales underestimate the predictive value of severe traumatic brain injury (TBI). There is no generally accepted classification of injury extent according to ISS scale, which makes comparing the results of different investigations difficult. Bolorunduro et al. [17] classify injuries as minor (ISS $<9$ scores), moderate (ISS 9-15 scores), severe (ISS 16-25 scores) and extremely severe (ISS >25 scores). Rozenfeld et al. [18] suggest more detailed ranking of extremely severe injuries in the intervals of $25-49,50-66$ and $67-75$ scores relying on the information from various databases. Other authors distinguish groups of the injured in the borderline (ISS 26-40 scores) and extreme (ISS >40 scores) conditions in classification of extremely severe trauma [19]. Mortality in trauma scored ISS $\geqslant 40$ is the highest and equals $65 \%$ [20].

Only one most severe injury within one body region is taken into account in ISS scoring system, while other prognostically relevant injuries remain uncounted, which leads to imprecise evaluation of polytrauma severity. This shortcoming is leveled to some extent in NISS (New Injury Severity Score) and APS (Anatomic Profile Score) scales. In NISS scoring system, trauma severity is calculated by summing the squares of scores awarded to three most severe injures irrespective of their localization [21]. NISS scoring system provides higher accuracy in predicting mortality from polytrauma than ISS [22], especially, in blunt trauma and among patients in critical condition [23-25], but it is not suitable for evaluating the injured in borderline condition [26].

In APS scoring system, trauma severity and survival probability are calculated based on the logistic regression equation taking into account injuries scored AIS $>3$ in three categories: A - injuries to the head and the spinal cord, B - chest and neck injuries, $\mathrm{C}$ - all other injuries of the same severity [27]. However, due to higher calculation complexity, APS scale has not replaced ISS.

In ICISS (the International Classification of Diseases (ICD-9) $9^{\text {th }}$ Edition Injury Severity Score), trauma severity is scored based on SRR (survival risk ratios) assigned to each found injury coded in ICD-9. In turn, SRR ratios are calculated by dividing the number of survivors by the total number of patients with this specific trauma [28]. Yet, independent SRR can be calculated only for the patients with isolated injuries, while many types of trauma are seldom present separately from other types in reality. Besides, AIS terminology describes injuries more accurately than ICD-9 codes. The data on ICISS classification effectiveness in mortality prediction are contradictory compared to ISS and NISS [23].

TMPM model (Trauma Mortality Prediction Model) is based on empiric evaluation of five most severe injuries 
calculated by the method of regression modeling using AIS or ICD-9 terminology [29]. TMPM model predicts mortality more accurately than ISS, AIS, NISS and ICISS systems [22, 25, 30].

Thus, some scoring systems analyze all injuries revealed and others evaluate only the most severe ones. There is no agreement of opinions as to which approach is more relevant for trauma outcome prediction. Certain types of injuries are also independent predictors of fatal polytrauma outcome: compound fracture of pelvic bones [31], spine and spinal cord injury in combined TBI [32], bilateral pulmonary contusion and rib fracture in combined chest injury [33], severe TBI or severe chest injury in combined pelvic trauma [34-36].

\section{Evaluating the severity of functional disorders}

Anatomical scoring systems do not reflect the functional state of the patient, which allows no correct stratification of patients with polytrauma according to fatal outcome risk [37].

GCS scale ranks the level of consciousness on a scale of 2 to 15 scores according to clinical parameters: eye opening, verbal response and motor response [38]. High sensitivity (79-97\%) and specificity (84-97\%) of the scale is observed in evaluating TBI severity and predicting death in polytrauma [32, 39, 40]. GCS score $\leqslant 8$ indicates severe TBI. In combined chest injury, GCS score $<13$ is considered to be a reliable predictor of unfavorable outcome [41, 42]. However, assessment of clinical parameters by GCS scale is quite subjective, which leads to variability of calculation results.

When a patient is admitted to the hospital, hypertension with systolic arterial blood pressure below 90-100 mm Hg due to blood loss and shock has been established to be an independent predictor of fatal outcome in presence of any trauma scored ISS $>16$ [7, 43], severe combined chest injury [33, 41, 42], abdominal injury $[40,44]$ or pelvic injury $[35,36]$. According to other data, heart rate and systolic arterial blood pressure level are no death predictors when considered separately, but shock index calculated as their ratio shows itself as a strong predictor of fatal outcome in elderly injured patients, if its value equals 1 and more [45]. However, in polytrauma, shock index has no significant relevance for evaluating trauma severity and blood loss as shock index value is considerably affected by comorbidities, alcoholic intoxication and some injuries, particularly, TBI [46]. For example, in case of combined TBI, both systolic arterial blood pressure above $160 \mathrm{~mm} \mathrm{Hg}$ on admission [47] and arterial hypotension events [32] are considered to be predictors of fatal outcome.

RTS (Revised Trauma Score) provides evaluation of the patient's conscious state according to GCS scale, systolic arterial blood pressure level and respiration rate. The sorting variant of the scale is more often used at pre-hospital stage and it is based on simple summing the coded parameter values. In the explorative variant, survival probability is calculated based on the logistic regression equation using the coefficients allowing taking into account the contribution of every indicator to the outcome [48]. RTS scale is effective in predicting mortality in polytrauma [24, 41], but it is inferior to ISS in this respect $[7,15]$.

The signs of acidosis, hypothermia and coagulopathy combined in the term "the lethal triad" evidence inadequate tissue perfusion, decompensation of homeostatic mechanisms with the threat of multisystem failure development and fatal polytrauma outcome [49, 50]. "The lethal triad" in polytrauma is associated with sustained severe traumatic injuries (ISS 30-35 scores) and considered to be an independent predictor of unfavorable outcome [51]. Mortality among the injured with "the lethal triad" amounts to $48 \%$ and with INR higher than 3.2 this figure reaches $100 \%$ [52].

Certain components of "the lethal triad" such as acidosis with blood $\mathrm{pH}$ below 7.2 [43], hypothermia below $35^{\circ} \mathrm{C}[44,53,54]$ or hypocoagulation [55-58] are also independent risk factors for unfavorable outcome. Hypothermia is associated with such polytrauma death predictors as blood loss, acidosis and coagulopathy [59]. Therefore, some authors consider hypothermia to be no independent risk factor for unfavorable outcome $[53,60]$. Many researchers determine the level of coagulopathy in polytrauma by INR increase. In such event, the threshold INR value relevant for prediction varies and, according to different data, amounts to more than 1.2 for children [61], more than 1.3 [59] or more $1.5[62,63]$. Besides, thrombocytopenia intensity, decrease the level of factors II and V [64] and fibrinogen (less than $2.29 \mathrm{~g} / \mathrm{L}$ ) have practical value for predicting unfavorable outcome and identifying the severity of the state in polytrauma [65]. Decrease in the ionized calcium content in venous blood less than $0.3 \mathrm{mmol} / \mathrm{L}$ and increase in activated partial thromboplastin time more than $59 \mathrm{~s}$ is associated with lethal outcome in degree III traumatic shock [49].

The indicators of base deficit, INR and GCS score are included in pediatric trauma BIG score which predicts unfavorable outcome of polytrauma quite accurately in adults as well, particularly, in trauma with penetrating injuries [12].

Coagulopathy and acidosis are associated with the level of blood lactate which also correlates with the severity of multisystem failure and mortality in polytrauma [34, 39, 66]. Some authors consider the level of blood lactate higher than $2 \mathrm{mmol} / \mathrm{L}$ relevant for prognosis [67], others find this value higher than $4.1 \mathrm{mmol} / \mathrm{L}$ to be predictive [49].

Total cholesterol level has been found to decline with trauma severity increasing, but only its subsequent increase to more than $90 \mathrm{mg} / \mathrm{L}$ in trauma scored ISS $\geqslant 20$ is considered to be a predictor of unfavorable outcome [68]. Corticosteroid insufficiency has been revealed in $53 \%$ of polytrauma patients and considered to be related to their critical condition. Yet it is not low initial cortisol 
level that is associated with unfavorable outcome, but the difference in its values after stimulation with adrenocorticotropic hormone of less than $9 \mu \mathrm{g} / \mathrm{dl}$ [69]. Serum cystatin C level increase to more than $0.93 \mathrm{mg} / \mathrm{L}$ correlates positively with severity of injuries according to ISS and mortality in polytrauma [70]. Ustyantseva et al. [71] consider the levels of apolipoprotein fractions used to determine compensated, sub-compensated and decompensated conditions to be the most informative metabolic parameters for severity evaluation in polytrauma patients.

Among oxidative stress indicators, only the serum levels of total oxidative status (hydrogen dioxide), but not total antioxidant capacity (6-hydroxy-2,5,7,8tetramethylchroman-2-carboxylic acid), correlated with mortality and severity of multiple blunt trauma identified according to ISS and RTS scales [72].

Hemoglobin level is an independent predictor of fatal polytrauma outcome [35, 43]. Erythrocyte count is relevant for predicting 30-day mortality in injured men, but not in women [73]. Total leucocyte count and differential leucocyte count have no predictive value, while the size of blood neutrophils on admission is reported to be a predictor of unfavorable outcome in the first week after polytrauma [74].

The probability of developing multisystem failure, sepsis and mortality in polytrauma grows with increasing number of criteria for systemic inflammatory response syndrome and its intensity level [75]. The prospects of various immune reaction markers (sIL-6R, pentraxin 3) [76], IL-1 $\beta$, IL-8, IL-10 [77] for evaluating severity and predicting complications and outcome in polytrauma are emphasized, but they are inaccessible for assessment and included in no evaluation scale.

The severity of a polytrauma patient's condition is affected by comorbidities which significantly increase the probability of fatal outcome and serve as its predictors $[11,24,78]$. Studying the influence of comorbidities on polytrauma severity and its outcome is complicated by the variety of somatic pathologies. The highest mortality rate in polytrauma $(32 \%)$ has been observed in patients with diabetes mellitus [79]. Obesity with body mass index $\geqslant 30$ is a risk factor for developing multisystem failure and fatal outcome in polytrauma patients [80, 81]. However, body mass index $<20$ proved to be even more relevant death predictor in polytrauma [82].

The age of the injured has a certain relationship with the presence of comorbidities as it correlates positively with hospital mortality index in polytrauma and is considered to be an independent predictor of unfavorable outcome by a number of studies [33, 34, 83]. According to some data, the threshold age when mortality among the injured starts to increase significantly is 55 years [13] or 60 years (mortality $41 \%$ ) [42, 84], other findings state the age of 65 years (mortality $31-50 \%$ ) [36, 85,86$]$ or 75 years (mortality 57\%) [57]. In patients with combined trauma over 65 years of age, systemic complications and death occur significantly more often even during the period of relative stability of their state [26]. In patients over 70 years of age, independent predictors of unfavorable outcome are proximal long-bone fractures [87] and spinal injury [88].

The gender of the injured is not associated with the level of hospital mortality in polytrauma, according to some investigations $[40,89]$. Other studies report the frequency of multisystem failure, sepsis, and hospital mortality among men with polytrauma to be significantly higher [11,90], particularly, in individuals older than 80 years [88].

To predict the outcome and evaluate the severity of state in polytrauma patients, it is proposed to apply APACHE II score calculator (Acute Physiology and Chronic Health Evaluation), MODS II (Multiple Organ Dysfunction Score II) [91], SOFA (Sequential Organ Failure Assessment) [39, 92], SAPS II (New Simplified Acute Physiology Score II) [93] and MPM II (Mortality Probability Models II) [94] in emergency departments. The given scoring systems involve a large number of various clinical and laboratory parameters, APACHE II, SAPS II, MPM II scales also take into account the age and comorbidities. Applicability of these scales in polytrauma is constantly disputed, they are not injuryspecific and reflect no severity of the damage. For example, in seriously injured patients requiring artificial lung ventilation, the severity of the condition according to APACHE II scale is higher, but the prognosis is more favorable than in non-trauma patients who also need artificial lung ventilation [95].

As to mortality prediction accuracy in polytrauma, APACHE II scale is superior to ISS, NISS [96], GCS [97] and is no inferior to SOFA scale [98]. According to other sources, ISS scale is either superior to APACHE II [3] or their data are similar in the efficiency of injury severity assessment and prediction of death risk [99]. APACHE II score of more than 8 points indicates the risk of fatal post-traumatic complications, which requires the patient to be taken to the intensive care unit [100].

Polytrauma assigned NISS and SAPS II scores positively correlates with predicted mortality [101]. When compared to SOFA scale, SAPS II scoring system accurately predicts 30-day mortality, and their combined use in polytrauma improves the accuracy of predicting adverse outcome [93].

Dubrov et al. [5] have proposed their original scale for evaluation of polytrauma patients' condition severity, including haemogram, hemodynamics, electrolyte and acid-base balance parameters, which allows physicians to score relatively stable and unstable condition of the injured.

\section{Combined systems of injury severity evaluation}

A number of prognostic systems used in polytrauma attempt to take into account two types of injury risk, anatomical and physiological.

PTS scale (Polytrauma Score, Hannover) is based on 
the numerical assessment of injuries in five anatomical areas and age, while the modified version of the scale additionally includes GCS scoring, the Horowitz coefficient $\left(\mathrm{PaO}_{2} / \mathrm{FiO}_{2}\right)$ value and the level of base deficit. The total score is assessed against 4 degrees of polytrauma severity: degree 1 - up to 20 points (predicted mortality of $10 \%$ ), degree $2-20$ to 34 points (mortality 25\%), degree $3-35-48$ points (mortality $50 \%$ ), degree 4 - above 48 points (mortality $75 \%$ ) [102].

TRISS system (Trauma and Injury Severity Score) allows physicians to calculate survival probability in case of multiple penetrating and blunt trauma by the formulas involving ISS, RTS scores and age (ranked as $\geqslant 55$ and $<55$ years) [103]. TRISS, along with APACHE II and SOFA scales, accurately predicts complications and death in intensive care unit patients [16, 83, 98, 104]. However, some authors have noted low accuracy of predicting unfavorable outcomes in polytrauma according to TRISS scale. According to some data, there is a high proportion of unpredicted deaths when this scale is used [105]. Other findings show that the scale has significantly overestimated the probability of death in polytrauma [26]. TRISS scale proved to be unsuitable for prediction of death in patients with combined injuries of the chest and abdomen in the first days of hospitalization [99].

GAP system (Glasgow Coma Scale, Age, and Systolic Blood Pressure Score) including GCS scale, age parameters (patients stratified as $\geqslant 60$ and $<60$ years) and systolic blood pressure value is easier to use, no different from TRISS scale and superior to RTS scale in polytrauma mortality prediction [106].

Unlike TRISS, ASCOT system (A Severity Characterization of Trauma) identifies 5 age groups and uses APS scale instead of ISS. ASCOT scale is characterized by greater survival prediction accuracy than TRISS, especially in patients with penetrating wounds, but it is more difficult to use [107]. According to other data, comparison of TRISS and ASCOT scales reveals no significant differences in outcome prediction accuracy in polytrauma patients [108].

PS09 scale (Probability of Survival; model 09) includes indicators of ISS, GCS scales, age, gender, the need for intubation and comparable to TRISS scale in mortality prediction accuracy [12].

In the scoring system, developed at the Department of Military Field Surgery (MFS) of the Military Medical Academy (Saint Petersburg), injury severity is determined by the maximum score of one of the two component parameters: the injury severity according to MFS-I scale (I - injury) and severity of condition calculated according to MFS-CA scale on admission and according to MFS-CH scale in the course of treatment, where $\mathrm{C}-$ condition, $\mathrm{A}-$ admission, $\mathrm{H}-$ hospital [109]. A certain advantage of these scales is the use of clinical and laboratory parameters available for assessment. But it has been found during the comparative analysis that MFS-I and MFS-CA scales are inferior to ISS and APACHE II scoring systems in the accuracy of trauma severity estimation and its outcome prediction $[3,110]$.

Pape et al. [64] have distinguished four degrees of condition severity in polytrauma patients based on systolic blood pressure, acidosis (lactate and base deficit levels), coagulopathy (thrombocytopenia levels, factors II and $\mathrm{V}$, and fibrinogen), hypothermia and tissue damage severity (chest, abdomen, pelvis, epithelial tissues): stable, borderline, unstable and critical. Allocation of the borderline condition has gained importance when providing a rationale for damage control strategy that obtained wide recognition in polytrauma treatment [5].

RISC II predictive model (Revised Injury Severity Classification II) involves the following predictors of fatal outcome in polytrauma: two highest AIS scores, AIS score for head injury, age, gender, reaction time and pupil size, motor function according to GCS scale, type of trauma (blunt or penetrating), the patient's condition assessment according to ASA scale (American Society of Anesthesiologists), systolic blood pressure, acidosis (base deficit), coagulopathy (INR) and hemoglobin, the need for cardiopulmonary resuscitation. Taking into account the two highest AIS scores, AIS score for head injury in separate variables significantly improved the predictive power of the model. Such variables as injury mechanism, severe fractures of the pelvis and shock index have not been included in RISC II and obtained no statistical significance [13]. RISC II system has high prediction accuracy and outperforms TRISS scale [2], but has less predictive value in polytrauma with severe TBI [111].

In addition to anatomical and physiological criteria, such factors as delay in hospitalization and untimely diagnosis [43], the need for massive blood transfusions $[7,44,86]$, artificial lung ventilation and emergency surgery [89] are considered to be independent predictors of fatal outcome in polytrauma. Other studies provide no evidence of the impact of the time period from injury to hospitalization and emergency surgeries on death risk $[13,24]$.

\section{Conclusion}

Quantitative approach based on predictive scoring systems is recognized to be the most suitable method for objective evaluation of polytrauma severity. Creating a universal scale is complicated by variety of injuries and disorders caused by polytrauma and insufficient study of injury outcome predictors. The proposed survival rates and prognostic factors are tied to specific polytrauma databases differing in terms of mortality and quality of medical care, which is reflected in their predictive value. A clear definition of polytrauma and formation of a unified system of assessing its severity would allow physicians to standardize treatment policy, perform comparative analysis of treatment results, objectively solve the problems of organization and financing medical aid to seriously injured people. 
Study Funding. This study was not supported by any financial sources.

Conflicts of Interest. The authors have no conflicts of interest to disclose.

\section{References}

1. von Rüden C., Woltmann A., Röse M., Wurm S., Rüger M., Hierholzer C., Bühren V. Outcome after severe multiple trauma: a retrospective analysis. J Trauma Manag Outcomes 2013; 7(1): 4, https://doi.org/10.1186/1752-2897-7-4.

2. Paffrath T., Lefering R., Flohé S.; Trauma Register DGU. How to define severely injured patients? - An Injury Severity Score (ISS) based approach alone is not sufficient. Injury 2014; 45(Suppl 3): S64-S69, https://doi.org/10.1016/j. injury.2014.08.020.

3. Berezka N.I., Litovchenko V.A., Garyachiy Y.V., Lapshin D.V., Morozova U.V. Optimization of surgical treatment patients with polytrauma using a scale evaluation of the damage severity and victims status. Nauchnye vedomosti BelGU. Meditsina. Farmatsiya 2014; 25(4): 116-119.

4. Wutzler S., Maegele M., Wafaisade A., Wyen H., Marzi I., Lefering R.; TraumaRegister DGU. Risk stratification in trauma and haemorrhagic shock: scoring systems derived from the TraumaRegister DGU ${ }^{\circledR}$. Injury 2014; 45(Suppl 3): S29-S34, https://doi.org/10.1016/j.injury.2014.08.014.

5. Dubrov V.E., Blazhenko A.N., Khanin M.Y., Gorbunov I.A., Blazhenko A.A., Kobritsov G.P., Khashagulgov G.M. Realization of damage control concept in acute period of polytrauma. Politravma 2012; 2: 68-73.

6. Boyko I.V., Zaft V.B., Lazarenko G.O. Organization of emergency medical care for patients with polytrauma at the stages of medical evacuation. Meditsina neotlozhnykh sostoyaniy 2013; 2(49): 77-84.

7. Di Saverio S., Gambale G., Coccolini F., Catena F., Giorgini E., Ansaloni L., Amadori N., Coniglio C., Giugni A., Biscardi A., Magnone S., Filicori F., Cavallo P., Villani S., Cinquantini F., Annicchiarico M., Gordini G., Tugnoli G. Changes in the outcomes of severe trauma patients from 15year experience in a Western European trauma ICU of Emilia Romagna region (1996-2010). A population cross-sectional survey study. Langenbecks Arch Surg 2014; 399(1): 109-126, https://doi.org/10.1007/s00423-013-1143-9.

8. Fröhlich M., Lefering R., Probst C., Paffrath T., Schneider M.M., Maegele M., Sakka S.G., Bouillon B., Wafaisade A; Committee on Emergency Medicine, Intensive Care and Trauma Management of the German Trauma Society Sektion NIS. Epidemiology and risk factors of multiple-organ failure after multiple trauma: an analysis of 31,154 patients from the TraumaRegister DGU. J Trauma Acute Care Surg 2014; 76(4): 921-928, https://doi.org/10.1097/ta.0000000000000199.

9. Butcher N., Balogh Z.J. AIS $>2$ in at least two body regions: a potential new anatomical definition of polytrauma. Injury 2012; 43(2): 196-169, https://doi.org/10.1016/j. injury.2011.06.029.

10. Pape H.C., Lefering R., Butcher N., Peitzman A., Leenen L., Marzi I., Lichte P., Josten C., Bouillon B., Schmucker U., Stahel P., Giannoudis P., Balogh Z. The definition of polytrauma revisited: an international consensus process and proposal of the new 'Berlin definition'. J Trauma Acute Care Surg 2014; 77(5): 780-786, https://doi.org/10.1097/ ta. 0000000000000453 .
11. Agadzhanyan V.V., Kravtsov S.A., Zheleznyakova I.A., Kornev A.N., Pachgin I.V. Integration of criteria of polytrauma severity degrees into the international classification of diseases. Politravma 2014; 1: 6-14.

12. Brockamp T., Maegele M., Gaarder C., Goslings J.C., Cohen M.J., Lefering R., Joosse P., Naess P.A., Skaga N.O., Groat T., Eaglestone S., Borgman M.A., Spinella P.C., Schreiber M.A., Brohi K. Comparison of the predictive performance of the BIG, TRISS, and PS09 score in an adult trauma population derived from multiple international trauma registries. Crit Care 2013; 17(4): R134, https://doi.org/10.1186/ cc12813.

13. Lefering R., Huber-Wagner S., Nienaber U., Maegele M., Bouillon B. Update of the trauma risk adjustment model of the TraumaRegister DGU ${ }^{\mathrm{TM}}$ : the Revised Injury Severity Classification, version II. Crit Care 2014; 18(5): 476, https://doi.org/10.1186/s13054-014-0476-2.

14. Baker S.P., O'Neill B., Haddon W. Jr., Long W.B. The injury severity score: a method for describing patients with multiple injuries and evaluating emergency care. J Trauma 1974; 14(3): 187-196, https://doi.org/10.1097/00005373$197403000-00001$.

15. Akhavan Akbari G., Mohammadian A. Comparison of the RTS and ISS scores on prediction of survival chances in multiple trauma patients. Acta Chir Orthop Traumatol Cech 2012; 79(6): 535-539.

16. Köseoğlu Z., Ozdoğan M., Kuvvetli A., Kösenli O., Oruç C., Onel S., Das K., Akova A. Increased nutritional risk in major trauma: correlation with complications and prolonged length of stay. Ulus Travma Acil Cerrahi Derg 2011; 17(6): 521524, https://doi.org/10.5505/tjtes.2011.28582.

17. Bolorunduro O.B., Villegas C., Oyetunji T.A., Haut E.R., Stevens K.A., Chang D.C., Cornwell E.E. 3rd, Efron D.T., Haider A.H. Validating the Injury Severity Score (ISS) in different populations: ISS predicts mortality better among Hispanics and females. J Surg Res 2011; 166(1): 40-44, https://doi.org/10.1016/j.jss.2010.04.012.

18. Rozenfeld M., Radomislensky I., Freedman L., Givon A., Novikov I., Peleg K. ISS groups: are we speaking the same language? Inj Prev 2014; 20(5): 330-335, https://doi. org/10.1136/injuryprev-2013-041042.

19. Sokolov V.A., Byalik E.I., Fayn A.M., Smolyar A.N., Evstigneev D.V. Management of unstable pelvic ring injuries in polytrauma patients at resuscitation stage. Politravma 2011; 2: 30-35.

20. Vyhnánek F., Fric M., Pažout J., Waldauf P., Očadlík M., Džupa V. Present concept for management of severely injured patients in Trauma Centre Faculty Hospital Královské Vinohrady. Cas Lek Cesk 2012; 151(10): 468-471.

21. Osler T., Baker S.P., Long W. A modification of the injury severity score that both improves accuracy and simplifies scoring. J Trauma 1997; 43(6): 922-926, https://doi. org/10.1097/00005373-199712000-00009.

22. Cook A., Weddle J., Baker S., Hosmer D., Glance L., Friedman L., Osler T. A comparison of the Injury Severity Score and the Trauma Mortality Prediction Model. J Trauma Acute Care Surg 2014; 76(1): 47-53, https://doi.org/10.1097/ ta.0b013e3182ab0d5d.

23. Tohira H., Jacobs I., Mountain D., Gibson N., Yeo A. Systematic review of predictive performance of injury severity scoring tools. Scand J Trauma Resusc Emerg Med 2012; 20: 63, https://doi.org/10.1186/1757-7241-20-63.

24. Belzunegui T., Gradín C., Fortún M., Cabodevilla A., 
Barbachano A., Sanz J.A. Major trauma registry of Navarre (Spain): the accuracy of different survival prediction models. Am J Emerg Med 2013; 31(9): 1382-1388, https://doi. org/10.1016/j.ajem.2013.06.026.

25. Haider A.H., Villegas C.V., Saleem T., Efron D.T., Stevens K.A., Oyetunji T.A., Cornwell E.E. 3rd, Bowman S., Haack S., Baker S.P., Schneider E.B. Should the IDC-9 Trauma Mortality Prediction Model become the new paradigm for benchmarking trauma outcomes? J Trauma Acute Care Surg 2012; 72(6): 1695-1701, https://doi.org/10.1097/ ta.0b013e318256a010.

26. Sulyma V.S., Kuz U.V. Assessment of the severity of the patients of different ages with combined skeletal injury and acute respiratory distress syndrome. Travma 2013; 14(3): 90-93.

27. Copes W.S., Champion H.R., Sacco W.J., Lawnick M.M., Gann D.S., Gennarelli T., MacKenzie E., Schwaitzberg S. Progress in characterizing anatomic injury. J Trauma 1990; 30(10): 1200-1207, https://doi. org/10.1097/00005373-199010000-00003.

28. Osler T., Rutledge R., Deis J., Bedrick E. ICISS: an international classification of disease- 9 based injury severity score. J Trauma 1996; 41(3): 380-388.

29. Osler T., Glance L., Buzas J.S., Mukamel D., Wagner J., Dick A. A trauma mortality prediction model based on the Anatomic Injury Scale. Ann Surg 2008; 247(6): 1041-1048, https://doi.org/10.1097/sla.0b013e31816ffb3f.

30. Cassidy L.D., Cook A., Ertl A., Gourlay D., Osler T. Is the Trauma Mortality Prediction Model (TMPM-ICD-9) a valid predictor of mortality in pediatric trauma patients? J Pediatr Surg 2014; 49(1): 189-192, https://doi.org/10.1016/j. jpedsurg.2013.09.055.

31. Cordts Filho Rde M., Parreira J.G., Perlingeiro J.A., Soldá S.C., Campos Td., Assef J.C. Pelvic fractures as a marker of injury severity in trauma patients. Rev Col Bras Cir 2011; 38(5): 310-316.

32. Puras Yu.V., Talypov A.E., Krylov V.V. Outcomes in patients with brain trauma associated with extracranial injuries on in-hospital stage of medical care. Zhurnal im. N.V. Sklifosovskogo. Neotlozhnaya meditsinskaya pomoshch' 2013; 1: 38-45.

33. Huber S., Biberthaler P., Delhey P., Trentzsch H., Winter H., van Griensven M., Lefering R., Huber-Wagner S.; TraumaRegister DGU. Predictors of poor outcomes after significant chest trauma in multiply injured patients: a retrospective analysis from the German Trauma Registry (Trauma Register DGU®). Scand J Trauma Resusc Emerg Med 2014; 22: 52, https://doi.org/10.1186/s13049-014-0052-4.

34. Haddad S.H., Yousef Z.M., Al-Azzam S.S., AlDawood A.S., Al-Zahrani A.A., AlZamel H.A., Tamim H.M., Deeb A.M., Arabi Y.M. Profile, outcome and predictors of mortality of abdomino-pelvic trauma patients in a tertiary intensive care unit in Saudi Arabia. Injury 2015; 46(1): 94-99, https://doi.org/10.1016/j.injury.2014.07.025.

35. Holstein J.H., Culemann U., Pohlemann T.; Working Group Mortality in Pelvic Fracture Patients. What are predictors of mortality in patients with pelvic fractures? Clin Orthop Relat Res 2012; 470(8): 2090-2097, https://doi.org/10.1007/s11999012-2276-9.

36. Gabbe B.J., de Steiger R., Esser M., Bucknill A., Russ M.K., Cameron P.A. Predictors of mortality following severe pelvic ring fracture: results of a population-based study. Injury 2011; 42(10): 985-991, https://doi.org/10.1016/j. injury.2011.06.003.
37. Mironov P.I, Junusov D.I., Gumerov A.A. Modern approaches to predict the outcome of severe combined trauma in children. Vestnik anesteziologii i reanimatologii 2013; 10(3): 56-61.

38. Teasdale G., Jennett B. Assessment of coma and impaired consciousness. A practical scale. Lancet 1974; 2(7872): 81-84, https://doi.org/10.1016/s0140-6736(74) 91639-0.

39. Galkova K., Vrabelova M. Normalization of blood lactate as early end-point of polytrauma treatment. Bratisl Lek Listy 2013; 114(11): 637-641, https://doi.org/10.4149/ bll_2013_136.

40. Agalaryan A.Kh. Surgical treatment and mortality in patients with abdominal injuries in polytrauma. Politravma 2014; (4): 24-31.

41. Emircan S., Ozgüç H., Akköse Aydın S., Ozdemir F., Köksal O., Bulut M. Factors affecting mortality in patients with thorax trauma. Ulus Travma Acil Cerrahi Derg 2011; 17(4): 329-333.

42. Liu Y., Du D.Y., Hu X., Xia D.K., Xiang X.Y., Zhou J.H., Liu C.B. Risk factors of mortality in severe chest trauma patients. Zhongguo Yi Xue Ke Xue Yuan Xue Bao 2013; 35(1): 74-79.

43. Alamshah S.M., Pipelzadeh M., Mousavi S.R., Baharanfar H., Rezapour E. Determination of predictors and risk factors in patients with multiple emergency surgical traumas. Ulus Travma Acil Cerrahi Derg 2010; 16(5): 421-426.

44. Kapan M., Onder A., Oguz A., Taskesen F., Aliosmanoglu I., Gul M., Tacyildiz I. The effective risk factors on mortality in patients undergoing damage control surgery. Eur Rev Med Pharmacol Sci 2013; 17(12): 1681-1687.

45. Pandit V., Rhee P., Hashmi A., Kulvatunyou N., Tang A., Khalil M., O'Keeffe T., Green D., Friese R.S., Joseph B. Shock index predicts mortality in geriatric trauma patients: an analysis of the National Trauma Data Bank. J Trauma Acute Care Surg 2014; 76(4): 1111-1115, https://doi.org/10.1097/ ta. 0000000000000160 .

46. Paladino L., Subramanian R.A., Nabors S., Sinert R. The utility of shock index in differentiating major from minor injury. Eur J Emerg Med 2011; 18(2): 94-98, https://doi. org/10.1097/mej.0b013e32833f212b.

47. Sellmann T., Miersch D., Kienbaum P., Flohé S., Schneppendahl J., Lefering R.; DGU Trauma Registry. The impact of arterial hypertension on polytrauma and traumatic brain injury. Dtsch Arztebl Int 2012; 109(49): 849-856.

48. Champion H.R., Sacco W.J., Copes W.S., Gann D.S., Gennarelli T.A., Flanagan M.E. A revision of the Trauma Score. J Trauma 1989; 29(5): 623-629, https://doi. org/10.1097/00005373-198905000-00017.

49. Stukanov M.M., Yudakova T.N., Maksimishin S.V., Girsh A.O., Stepanov S.S. The indicators associated with lethal outcomes in patients with traumatic shock. Politravma 2015; 2 : $37-43$.

50. Davenport R. Pathogenesis of acute traumatic coagulopathy. Transfusion 2013; 53(Suppl 1): 23S-27S, https://doi.org/10.1111/trf.12032.

51. González Balverde M., Ramírez Lizardo E.J., Cardona Muñoz E.G., Totsuka Sutto S.E., García Benavides L. Prognostic value of the lethal triad among patients with multiple trauma. Rev Med Chil 2013; 141(11): 1420-1426, https://doi. org/10.4067/s0034-98872013001100008.

52. Mitra B., Tullio F., Cameron P.A., Fitzgerald M. Trauma 
patients with the 'triad of death'. Emerg Med J 2012; 29(8): 622-625, https://doi.org/10.1136/emj.2011.113167.

53. Mommsen P., Andruszkow H., Frömke C., Zeckey C., Wagner U., van Griensven M., Frink M., Krettek C., Hildebrand F. Effects of accidental hypothermia on posttraumatic complications and outcome in multiple trauma patients. Injury 2013; 44(1): 86-90, https://doi.org/10.1016/j. injury.2011.10.013.

54. Ireland S., Endacott R., Cameron P., Fitzgerald M., Paul E. The incidence and significance of accidental hypothermia in major trauma - a prospective observational study. Resuscitation 2011; 82(3): 300-306, https://doi. org/10.1016/j.resuscitation.2010.10.016.

55. Müller M.C., Balvers K., Binnekade J.M., Curry N., Stanworth S., Gaarder C., Kolstadbraaten K.M., Rourke C., Brohi K., Goslings J.C., Juffermans N.P. Thromboelastometry and organ failure in trauma patients: a prospective cohort study. Crit Care 2014; 18(6): 687, https://doi.org/10.1186/ s13054-014-0687-6.

56. Theusinger O.M., Wanner G.A., Emmert M.Y., Billeter A., Eismon J., Seifert B., Simmen H.P., Spahn D.R., Baulig W. Hyperfibrinolysis diagnosed by rotational thromboelastometry (ROTEM) is associated with higher mortality in patients with severe trauma. Anesth Analg 2011; 113(5): 1003-1012, https:// doi.org/10.1213/ane.0b013e31822e183f.

57. Schoeneberg C., Probst T., Schilling M., Wegner A., Hussmann B., Lendemans S. Mortality in severely injured elderly patients: a retrospective analysis of a German level 1 trauma center (2002-2011). Scand J Trauma Resusc Emerg Med 2014; 22: 45, https://doi.org/10.1186/s13049-014-0045-3.

58. Sakellaris G., Blevrakis E., Petrakis I., Dimopoulou A., Dede O., Partalis N., Alegakis A., Seremeti C., Spanaki A.M., Briassoulis G. Acute coagulopathy in children with multiple trauma: a retrospective study. J Emerg Med 2014; 47(5): 539545, https://doi.org/10.1016/j.jemermed.2014.06.018.

59. Kutcher M.E., Howard B.M., Sperry J.L., Hubbard A.E., Decker A.L., Cuschieri J., Minei J.P., Moore E.E., Brownstein B.H., Maier R.V., Cohen M.J. Evolving beyond the vicious triad: differential mediation of traumatic coagulopathy by injury, shock, and resuscitation. J Trauma Acute Care Surg 2015; 78(3): 516-523, https://doi.org/10.1097/ ta. 0000000000000545 .

60. Søreide K. Clinical and translational aspects of hypothermia in major trauma patients: from pathophysiology to prevention, prognosis and potential preservation. Injury 2014; 45(4): 647-654, https://doi.org/10.1016/j. injury.2012.12.027.

61. Whittaker B., Christiaans S.C., Altice J.L., Chen M.K., Bartolucci A.A., Morgan C.J., Kerby J.D., Pittet J.F. Early coagulopathy is an independent predictor of mortality in children after severe trauma. Shock 2013; 39(5): 421-426, https://doi.org/10.1097/shk.0b013e31828e08cb.

62. Peltan I.D., Vande Vusse L.K., Maier R.V., Watkins T.R. An international normalized ratio-based definition of acute traumatic coagulopathy is associated with mortality, venous thromboembolism, and multiple organ failure after injury. Crit Care Med 2015; 43(7): 1429-1438, https://doi.org/10.1097/ ccm.0000000000000981.

63. Brown J.B., Cohen M.J., Minei J.P., Maier R.V., West M.A., Billiar T.R., Peitzman A.B., Moore E.E., Cuschieri J., Sperry J.L.; Inflammation and the Host Response to Injury Investigators. Characterization of acute coagulopathy and sexual dimorphism after injury: females and coagulopathy just do not mix. J Trauma Acute Care Surg 2012; 73(6): 13951400, https://doi.org/10.1097/ta.0b013e31825b9f05.

64. Pape H.C., Giannoudis P.V., Krettek C., Trentz O. Timing of fixation of major fractures in blunt polytrauma: role of conventional indicators in clinical decision making. $J$ Orthop Trauma 2005; 19(8): 551-562, https://doi.org/10.1097/01. bot.0000161712.87129.80.

65. Hagemo J.S., Stanworth S., Juffermans N.P., Brohi K., Cohen M., Johansson P.I., Røislien J., Eken T., Næss P.A., Gaarder C. Prevalence, predictors and outcome of hypofibrinogenaemia in trauma: a multicentre observational study. Crit Care 2014; 18(2): R52, https://doi.org/10.1186/ cc13798.

66. Parsikia A., Bones K., Kaplan M., Strain J., Leung P.S., Ortiz J., Joshi A.R. The predictive value of initial serum lactate in trauma patients. Shock 2014; 42(3): 199-204, https://doi. org/10.1097/shk.0000000000000208.

67. Guyette F., Suffoletto B., Castillo J.L., Quintero J., Callaway C., Puyana J.C. Prehospital serum lactate as a predictor of outcomes in trauma patients: a retrospective observational study. J Trauma 2011; 70(4): 782-786, https:// doi.org/10.1097/ta.0b013e318210f5c9.

68. Dunham C.M., Chirichella T.J. Attenuated hypocholesterolemia following severe trauma signals risk for late ventilator-associated pneumonia, ventilator dependency, and death: a retrospective study of consecutive patients. Lipids Health Dis 2011; 10: 42, https://doi.org/10.1186/1476511x-10-42.

69. Yang Y., Liu L., Jiang D., Wang J., Ye Z., Ye J., Chao J., Zhao M., Ao D., Qiu H. Critical illness-related corticosteroid insufficiency after multiple traumas: a multicenter, prospective cohort study. J Trauma Acute Care Surg 2014; 76(6): 13901396, https://doi.org/10.1097/ta.0000000000000221.

70. Şentürk G.Ö., Ünlüer E.E., Vandenberk N., Yavaşi Ö., Eroglu O., Sürüm N., Üstüner F., Kayayurt K. The prognostic value of cystatin $\mathrm{C}$ compared with trauma scores in multiple blunt trauma: a prospective cohort study. J Emerg Med 2013; 44(6): 1070-1076, https://doi.org/10.1016/j. jemermed.2012.11.037.

71. Ustyantseva I.M., Khokhlova O.I., Petukhova O.V., Krupko O.V., Zhevlakova Y.A., Agadzhanyan V.V. Development of pathogenetic methods of diagnostics, evaluation of state severity and injuries in polytrauma. Politravma 2010; 1: 34-38.

72. Gokdemir M.T., Sogut O., Kaya H., Sayhan M.B., Cevik M., Dokuzoglu M.A., Boleken M.E. Role of oxidative stress in the clinical outcome of patients with multiple blunt trauma. J Int Med Res 2012; 40(1): 167-173, https://doi.org/10. $1177 / 147323001204000117$.

73. Majercik S., Fox J., Knight S., Horne B.D. Red cell distribution width is predictive of mortality in trauma patients. J Trauma Acute Care Surg 2013; 74(4): 1021-1026, https://doi. org/10.1097/ta.0b013e3182826f02.

74. Lam S.W., Leenen L.P., van Solinge W.W., Hietbrink F., Huisman A. Comparison between the prognostic value of the white blood cell differential count and morphological parameters of neutrophils and lymphocytes in severely injured patients for 7-day in-hospital mortality. Biomarkers 2012; 17(7): 642-647, https://doi.org/10.3109/1354750x.2012.712161.

75. Baek J.H., Kim M.S., Lee J.C., Lee J.H. Systemic inflammation response syndrome score predicts the mortality in multiple trauma patients. Korean $J$ Thorac Cardiovasc Surg 2014; 47(6): 523-528, https://doi.org/10.5090/ kjtcs.2014.47.6.523. 
76. Kleber C., Becker C.A., Schmidt-Bleek K., Schaser K.D., Haas N.P. Are pentraxin 3 and transsignaling early markers for immunologic injury severity in polytrauma? A pilot study. Clin Orthop Relat Res 2013; 471(9): 2822-2830, https://doi.org/10.1007/s11999-013-2922-x.

77. Dorzheev V.V. The content of IL-1 $\beta$, IL-2, IL-8, IL-10 and TNFa in patients with polytrauma. Zabaykal'skiy meditsinskiy vestnik 2014; 4: 132-135.

78. Miller C.M., Shi J., Wheeler K.K., Yin H., Smith G.A., Groner J.I., Xiang H. Chronic conditions and outcomes of pediatric trauma patients. J Trauma Acute Care Surg 2013; 75(2): 250-257, https://doi.org/10.1097/ta. Ob013e3182930fb7.

79. Tebby J., Lecky F., Edwards A., Jenks T., Bouamra O., Dimitriou R., Giannoudis P.V. Outcomes of polytrauma patients with diabetes mellitus. BMC Med 2014; 12: 111, https://doi. org/10.1186/1741-7015-12-111.

80. Liu T., Chen J.J., Bai X.J., Zheng G.S., Gao W. The effect of obesity on outcomes in trauma patients: a meta-analysis. Injury 2013; 44(9): 1145-1152, https://doi. org/10.1016/j.injury.2012.10.038.

81. Andruszkow H., Veh J., Mommsen P., Zeckey C., Hildebrand F., Frink M. Impact of the body mass on complications and outcome in multiple trauma patients: what does the weight weigh? Mediators Inflamm 2013; 2013: 345702, https://doi.org/10.1155/2013/345702.

82. Hoffmann M., Lefering R., Gruber-Rathmann M., Rueger J.M., Lehmann W.; Trauma Registry of the German Society for Trauma Surgery. The impact of BMI on polytrauma outcome. Injury 2012; 43(2): 184-188, https://doi.org/10.1016/j. injury.2011.05.029.

83. Sousa A.N., Paiva J.A., Fonseca S.A., Raposo F.J., Loureiro A.M., Valente L.F., Gonçalves A.M., Cabral A.T., Almeida L. Trauma scores in the management of politrauma patients: which one and what for? Acta Med Port 2011; 24(6): 943-950.

84. Levchenko T.V., Kravtsov S.A., Kornev A.N., Shatalin A.V., Dzuban G.G. Analysis of hospital mortality and clinical diagnostics quality in patients with polytrauma. Politravma 2014; 3: 24-32.

85. Grzalja N., Saftić I., Marinović M., Stiglić D., Cicvarić T. Polytrauma in elderly. Coll Antropol 2011; 35(Suppl 2): 231-234.

86. Wu J., Sheng L., Wang S., Li Q., Zhang M., Xu S., Gan J. Analysis of clinical risk factors associated with the prognosis of severe multiple-trauma patients with acute lung injury. J Emerg Med 2012; 43(3): 407-412, https://doi. org/10.1016/j.jemermed.2009.05.024.

87. Werman H.A., Erskine T., Caterino J., Riebe J.F., Valasek T.; Members of the Trauma Committee of the State of Ohio EMS Board. Development of statewide geriatric patients trauma triage criteria. Prehosp Disaster Med 2011; 26(3): 170179, https://doi.org/10.1017/s1049023x11006315.

88. O'Neill S., Brady R.R., Kerssens J.J., Parks R.W. Mortality associated with traumatic injuries in the elderly: a population based study. Arch Gerontol Geriatr 2012; 54(3): e426-e430, https://doi.org/10.1016/j.archger.2012.01.007.

89. Jin H., Tang L.Q., Pan Z.G., Peng N., Wen Q., Tang Y.Q., Su L. Ten-year retrospective analysis of multiple trauma complicated by pulmonary contusion. Mil Med Res 2014; 1(1): 7, https://doi.org/10.1186/2054-9369-1-7.

90. Trentzsch H., Lefering R., Nienaber U., Kraft R., Faist E., Piltz S. The role of biological sex in severely traumatized patients on outcomes: a matched-pair analysis. Ann Surg 2015; 261(4): 774-780, https://doi.org/10.1097/ sla.0000000000000789.

91. Khanin M.Yu. Anemia correction in patients with multiple and concomitant skeletal muscular system injures. Meditsinskiy vestnik Bashkortostana 2012; 7(2): 78-80.

92. Dewar D.C., White A., Attia J., Tarrant S.M., King K.L., Balogh Z.J. Comparison of postinjury multiple-organ failure scoring systems: Denver versus Sequential Organ Failure Assessment. J Trauma Acute Care Surg 2014; 77(4): 624-629, https://doi.org/10.1097/ta.0000000000000406.

93. Fueglistaler P., Amsler F., Schüepp M., FueglistalerMontali I., Attenberger C., Pargger H., Jacob A.L., Gross T. Prognostic value of Sequential Organ Failure Assessment and Simplified Acute Physiology II Score compared with trauma scores in the outcome of multiple-trauma patients. Am J Surg 2010; 200(2): 204-214, https://doi.org/10.1016/j. amjsurg.2009.08.035.

94. Potanina O.K., Dorfman A.G., Ogurtsova E.V., Shvirev S.L., Zarubina T.V. Estimation efficiency and comparison of several prognostic scoring systems in several diagnostic groups for ICU patients of surgical profile. Informatsionnoizmeritel'nye i upravlyayushchie sistemy 2011; 9(12): 75-81.

95. Santana-Cabrera L., Sánchez-Palacios M., Rodríguez A.U. Differences in the prognosis among severe trauma and medical patients requiring mechanical ventilation. Int J Burns Trauma 2013; 3(4): 220-224.

96. Mica L., Rufibach K., Keel M., Trentz O. The risk of early mortality of polytrauma patients associated to ISS, NISS, APACHE II values and prothrombin time. J Trauma Manag Outcomes 2013; 7: 6, https://doi.org/10.1186/1752-2897-7-6.

97. Zali A.R., Seddighi A.S., Seddighi A., Ashrafi F. Comparison of the acute physiology and chronic health evaluation score (APACHE) II with GCS in predicting hospital mortality of neurosurgical intensive care unit patients. Glob J Health Sci 2012; 4(3): 179-184, https://doi.org/10.5539/gjhs. v4n3p179.

98. Hwang S.Y., Lee J.H., Lee Y.H., Hong C.K., Sung A.J., Choi Y.C. Comparison of the Sequential Organ Failure Assessment, Acute Physiology and Chronic Health Evaluation II scoring system, and Trauma and Injury Severity Score method for predicting the outcomes of intensive care unit trauma patients. Am J Emerg Med 2012; 30(5): 749-753, https://doi.org/10.1016/j.ajem.2011.05.022.

99. Sorokin E.P., Gritsan A.I., Ponomarev S.V., Shilyaeva E.V. Experience of prognostic scales to assess survival in patients with combined injuries chest and abdomen. Vestnik anesteziologii i reanimatologii 2013; 10(5): 47-50.

100. Govorov V.V., Govorova N.V., Mangus A.E. Prognostic evaluation of values of main life support systems and APACHE II in patients with severe concomitant injury. Politravma 2011; 2: 42-47.

101. Sardinha D.S., de Sousa R.M., Nogueira Lde S., Damiani L.P. Risk factors for the mortality of trauma victims in the intensive care unit. Intensive Crit Care Nurs 2015; 31(2): 76-82, https://doi.org/10.1016/j.iccn.2014.10.008.

102. Oestern H.J., Tscherne H., Sturm J., Nerlich M. Classification of the severity of injury. Unfallchirurg 1985; 88(11): 465-472.

103. Boyd C.R., Tolson M.A., Copes W.S. Evaluating trauma care: the TRISS method. Trauma Score and the Injury Severity Score. J Trauma 1987; 27(4): 370-378.

104. Thanapaisal C., Saksaen P. A comparison of the Acute 
Physiology and Chronic Health Evaluation (APACHE) II score and the Trauma-Injury Severity Score (TRISS) for outcome assessment in Srinagarind Intensive Care Unit trauma patients. J Med Assoc Thai 2012; 95(Suppl 11): S25-S33.

105. Deshmukh V.U., Ketkar M.N., Bharucha E.K. Analysis of trauma outcome using the TRISS method at a Tertiary Care Centre in Pune. Indian J Surg 2012; 74(6): 440-444, https:// doi.org/10.1007/s12262-011-0404-5.

106. Ahun E., Köksal Ö., Sığırlı D., Torun G., Dönmez S.S., Armağan E. Value of the Glasgow coma scale, age, and arterial blood pressure score for predicting the mortality of major trauma patients presenting to the emergency department. Ulus Travma Acil Cerrahi Derg 2014; 20(4): 241247, https://doi.org/10.5505/tjtes.2014.76399.

107. Champion H.R., Copes W.S., Sacco W.J., Frey C.F., Holcroft J.W., Hoyt D.B., Weigelt J.A. Improved predictions from a severity characterization of trauma (ASCOT) over
Trauma and Injury Severity Score (TRISS): results of an independent evaluation. J Trauma 1996; 40(1): 42-49, https:// doi.org/10.1097/00043860-199604000-00008.

108. Török Á., Bancu Ş., Neagoe R., Mureşan M., Kántor T., Suciu A., Vas K.E., Nagy Ö. The utility of the predictive scores in polytrauma with abdomino-pelvic injuries: a series of 38 patients. Chirurgia (Bucur) 2014; 109(1): 44-47.

109. Gumanenko E.K. Ob"ektivnaya otsenka tyazhesti travmy [An objective assessment of severity of the injury]. Saint Petersburg; 1999, 109 p.

110. Apartsin K.A. Combined trauma surgery. Sibirskiy meditsinskiy zhurnal (Irkutsk) 2014; 126(3): 129-133.

111. Raj R., Brinck T., Skrifvars M.B., Kivisaari R., Siironen J., Lefering R., Handolin L. Validation of the revised injury severity classification score in patients with moderate-tosevere traumatic brain injury. Injury 2015; 46(1): 86-93, https:// doi.org/10.1016/j.injury.2014.08.026. 